\title{
Real Sources of European Currency Policy: Sectoral Interests and European Monetary Integration
}

\section{Citation}

Frieden, Jeffry A. 2002. Real sources of European currency policy: Sectoral interests and European monetary integration. International Organization 56(4): 831-860.

\section{Published Version}

http://dx.doi.org/10.1162/002081802760403793

\section{Permanent link}

http://nrs.harvard.edu/urn-3:HUL.InstRepos:2579737

\section{Terms of Use}

This article was downloaded from Harvard University's DASH repository, and is made available under the terms and conditions applicable to Other Posted Material, as set forth at http:// nrs.harvard.edu/urn-3:HUL.InstRepos:dash.current.terms-of-use\#LAA

\section{Share Your Story}

The Harvard community has made this article openly available. Please share how this access benefits you. Submit a story.

Accessibility 


\title{
Real Sources of European Currency Policy: Sectoral Interests and European Monetary Integration
}

\author{
Jeffry A. Frieden
}

For more than thirty years, until the completion of Economic and Monetary Union (EMU), the member states of the European Union (EU) attempted to fix regional exchange rates. Naturally enough, most explanations of this process emphasize its monetary sources and effects. Some focus on how creating a multinational currency area might increase the efficacy of monetary policy. Others stress how fixing a national currency to a low-inflation monetary anchor, or adopting a single lowinflation currency, might enhance the anti-inflationary credibility of national monetary policies. ${ }^{1}$ In these views, European monetary integration was motivated by the belief that, by themselves, national monetary authorities would be unable or unwilling to pursue appropriate monetary policies.

In this article, I focus, in contrast, on what might be called real as opposed to monetary sources and effects of European currency policies-that is, their expected impact on cross-border trade and investment. Exchange rates regulate the relationship between foreign and domestic prices, and thus the predictability and profitability of cross-border trade and investment. Rather than restrict my analysis to monetary reasons for exchange rate policies, I suggest examining motivations that come from the country's trade, financial, and investment ties. In this view, policymakers weighed the costs and benefits of fixed exchange rates with regard to their impact on national trade and investment. The principal benefit of fixed rates and a single currency was to facilitate intra-European trade and investment; the principal

The author acknowledges the invaluable research assistance of Kathleen O'Neill and Mark Copelovitch. He also acknowledge s the comments and suggestions of Alberto Alesina, S. Brock Blomberg, William Clark, Michele Fratianni, Geoffrey Garrett, Carsten Hefeker, David Leblang, Lisa Martin, Andrew Moravcsik, J. David Richardson, Andrew Rose, and of participants in seminars at Harvard University, Princeton University, Syracuse University, the University of California Los Angeles, and Washington University.

1. Another broader perspective looks at how EMU was linked to the general drive for European integration. Accurate as this may be-for an argument in its favor see Frieden 2001-it still relies on implicit assertions about the ultimate costs and benefits of monetary integration. Most such assertions focus, as do the two mentioned here, on the monetary (anti-inflationary) aspects of the process.

International Organization 56, 4, Autumn 2002, pp. 831-860

(C) 2002 by The IO Foundation and the Massachusetts Institute of Technology 
cost was losing the ability to manipulate currencies to change the relative prices of foreign and home products and thus the competitive position of national producers. The various weights that different economic interests gave to these costs and benefits help explain the political economy of European monetary integration.

While this real interpretation of national currency policies might be consistent with explanations based on their monetary policy effects, it does lead to a very different emphasis, particularly with regard to the political supporters and opponents of monetary integration. Arguments based on anti-inflationary credibility and Optimal Currency Areas (OCAs) emphasize economic efficiency or very broad constituencies with different degrees of inflation aversion; the real argument here implicates much more specific distributional factors. In particular, it predicts support for monetary integration from cross-border investors and exporters of specialized manufactures who stand to lose from currency volatility. It anticipates opposition from those, especially import competers, who stand to lose from the inability of national governments to engage in depreciations to gain international competitiveness.

The European experience provides a useful laboratory to investigate these claims. Over three decades, European currency relations experienced a great deal of variation. The snake and early European Monetary System (EMS) had only limited success, while the later EMS went through a cycle of optimism, crisis, and renewed optimism in the runup to EMU. While some countries were generally able to persist in pegging their exchange rates to the deutsche mark (DM), others were quite unsuccessful for long periods of time. This allows us to assess both why the fortunes of fixed rates varied over time and why their attainment varied so much among European countries. I suggest that the answers to these questions require prominent consideration of the sectoral implications of currency policy's real impact, especially how fixing the exchange rate was expected to affect both those with strong interests in expanding inter-regional trade, finance, and investment and those with strong interests in limiting the impact on them of foreign competition. In this article, I look at the statistical record of exchange rate movements in Europe from 1973 until 1995. Although it is extremely difficult to find good proxies for interest-group pressures, especially in a cross-national context, I use two measures as indicators of private-sector concerns about the real effects of currency policy. The first is the level of manufactured exports to Germany, as a proxy for the interests of internationally engaged producers and investors who wanted to stabilize exchange rates. The second is changes in the trade balance (controlling for the state of the current account), which should reflect the level of concern about import and export competition. These measures have empirically important and statistically significant effects on both the rate of devaluation of national currencies against the DM and on their volatility (two closely related policy outcomes). Countries with more manufactured exports to Germany were more likely to sustain a currency fixed to the DM, consistent with the argument that exporters of complex manufactures were interested in currency stability. Periods of deterioration in the trade balance were associated with more subsequent floating and depreciation, consistent with the 
argument that difficulties in import and export markets led affected interests to support depreciation to improve their competitive position.

Other factors also affected exchange rates. Positive macroeconomic trendseconomic growth, a payments surplus, improvements in the terms of trade-reduced the propensity to devalue and currency volatility. There is little evidence for the explanatory importance of purely monetary considerations, such as the need for national anti-inflationary credibility - although admittedly the demand for credibility is extremely hard to measure. For example, countries with left-wing governments, presumably in greater need of anti-inflationary credibility, were not more likely to fix their currencies, and fixing the exchange rate was not more likely to be used when the country lacked an independent central bank. This is not to say that anti-inflationary credibility was never a reason why governments fixed their exchange rates, only that it is difficult to find evidence of its significance in the case of European monetary integration. Nor is much support found for OCA factors, specifically the similarity of industrial structure among countries and thus their propensity to face conditions that would call for similar monetary responses.

These results indicate that European currency policies were strongly affected by their expected real effects, that is, their impact on trade and investment. The results do not support-but cannot conclusively reject-monetary interpretations of European currency relations based on the anti-inflationary credibility-enhancing features of a fixed exchange rate or on OCA considerations. I begin with a summary of possible explanations of European monetary integration and how they relate to broader political economy arguments. I then argue for the role of real factors, and their distributional impact, in the evolution of European currency policies, and go on to present statistical evidence relating to the argument.

\section{European Monetary Integration: Variation and Explanation}

The ultimate success of European monetary integration has tended to obscure the variegated history of the region's currency policies. In fact, exchange-rate arrangements in the EU have gone through many stages, and the policies of EU member governments have varied widely. The first formal attempt to create a European zone of monetary stability came as the Bretton Woods system collapsed, with the 1973 formation of the "snake in the tunnel." Within a few months, only Germany, the Netherlands, and Belgium/Luxembourg (which shared a currency) were full participants, with Denmark sometimes included; this remained the case until 1979. In that

2. Such expressions of intent predate the Treaty of Rome, although their relevance was limited before the Bretton Woods system began to collapse. In this article, I call the organization in question the EU, despite its several names in the period under review. For a less telegraphic survey of these developments, see Frieden 1997a. For a detailed analysis, which is roughly consistent with the argument here, see Moravcsik 1998, 238-313. 
year, a new EMS and its exchange-rate mechanism (ERM) came into operation. The EMS appeared to have added little to the snake for its first five years: only Germany and the Benelux countries, and now more reliably Denmark, were able to keep their currencies more or less aligned. But between 1983 and 1985, France, Italy, and Ireland began to lock their currencies to the DM.

From 1985 until 1992, the monetary unification process gained momentum, eventually attracting such improbable candidates as the United Kingdom (long unwilling) and Spain and Portugal (long unable). The Nordic countries and Austria, not EU members but considering joining, also tied their currencies to the EMS. In this setting, member states began to plan for a common European currency within a broader EMU. Progress toward this goal was interrupted in 1992-94, as tight German monetary policy in the aftermath of German unification drove many EMS members to let their exchange rates move-with at least a widening of the acceptable target zone and at most a substantial depreciation. Momentum for EMU was rebuilt after the currency crises faded. Eleven EU members started the final steps toward a single currency in 1999 , Greece joined in 2000 , and these twelve finalized full currency union in 2002.

We can use these dimensions of variation to evaluate explanations of European monetary integration specifically and of currency policy more generally. Attempts to hold to fixed exchange rates ${ }^{3}$ were more successful at some times than at others in Europe. In addition, EU members had highly varied experiences within the snake and EMS. Therefore, meaningful variation occurs both over time and among countries.

\section{The Dependent Variables}

The policy choice most in need of explanation can be expressed simply: the degree of fixity of the nominal exchange rate to the DM. This definition of the thing to be explained, which might be questionable in other historical and regional contexts, is justifiable in post-1973 Europe. First, exchange rate stability was a publicly stated goal of all EU members. Second, it was clear early on that such stability implied fixing against the DM. Third, the attention of all relevant actors-policymakers, observers, economic agents—was on nominal exchange rates. ${ }^{4}$

The statistical analyses use two simple measures of trends in national currency values against the DM. The first is the annual rate of nominal depreciation, which

3. For simplicity, I consider the target zones of the snake and ERM equivalent to a fixed-rate system. This raises two problems. First, target zones imply fixing within a much broader range than is usually associated with fixed rates. However, the general policy problem is similar, especially when-as has been the case-currencies have often reached the limits of their bands. Second, the acceptable bands were substantially widened in the aftermath of the 1992-94 crises, so this first point may be less valid recently. However, with the exception of the Irish pound, most currencies that stayed within the wider-band ERM kept roughly inside their previous narrow band, and the Irish pound appreciated (as sterling rose), which represents a less troubling policy problem than the more common pressure to depreciate.

4. I avoid the stronger claim that nominal and real exchange rates were tightly linked in the period, even though there is substantial evidence for this in almost all European countries. 
directly measures the general trend of the currency against the DM anchor. (All European currencies decline relative to the DM over the period, so there are no appreciating currencies.) The second measure is the annual coefficient of variation of monthly exchange rates. This gauges shorter-term volatility within each year rather than the trend of the currency's value.

Table 1 shows these two measures of the stability of European currencies against the DM. The table includes the thirteen pre-EMU EU currencies other than the DM (Luxembourg shared a currency with Belgium), plus that of Norway. ${ }^{5}$ The table is divided among four groups: hard-currency countries are those that were always members of both the snake and the ERM, soft-currency countries are those that were not reliable members of either, and intermediate countries are those that were members of the ERM but not the snake. The four countries that were not in the EU before 1995 (one of which, Norway, remains a nonmember) are shown separately.

The simplest way to measure the relationship between exchange rates is the rate of change in their nominal values, in this case the average annual rate of depreciation against the DM, as presented in panel A of Table 1. This has the advantage of transparency of interpretation; however, it does not indicate potential currency volatility. For this purpose, the coefficient of variation of national currencies against the DM is presented in panel B of Table $1 .^{6}$ The two measures produce very similar classifications of countries and country-years, and when used in statistical analysis, they give rise to virtually identical results. However, the differences are also interesting, as they pick up (inasmuch as they differ) differences between determinants of broad currency policy and of shorter-term policy toward volatility.

\section{Explaining European Currency Policies}

The varied progress and nature of European currency arrangements has attracted much analysis. Three common explanations of European monetary integration are relevant; they can be considered in the rough order in which they gained academic currency. ${ }^{7}$ The first set of explanations emphasized criteria associated with OCA theory. ${ }^{8}$ OCA theory specifies circumstances under which it is optimal for a nation

5. There might be an argument for including Iceland and Switzerland, except that neither has expressed real commitment to European currency stability. Iceland has had relatively high and variable inflation, and Switzerlands international financial role makes purely European considerations somewhat less relevant.

6. The coefficient of variation is the standard deviation divided by the mean; in Table 1, currency values are taken at monthly intervals so that the volatility being measured is monthly over the periods in question, which are of five or six years. For the statistical analyses, the value is the volatility of monthly exchange rates over each country-year. This picks up both overall declines against the DM and general volatility, so that differences between the two dependent variables are presumably ascribable to different determinants of volatility itself (as opposed to depreciation).

7. The European literature discussed here parallels that described in Bernhard, Broz, and Clark 2002.

8. Mundell 1961; McKinnon 1963; and Kenen 1969 are early classics; Masson and Taylor 1993; and Tavlas 1994 are more recent surveys. 
836 International Organization

TABLE 1. European currencies during the snake and the EMS

A. Average annual percentage depreciation of nominal exchange rates against the DM, select periods $\begin{array}{lll}1973-78 & 1999-83 & 1984-89\end{array}$

\begin{tabular}{|c|c|c|c|c|}
\hline \multicolumn{5}{|l|}{ Hard Currencies } \\
\hline Netherlands & 1.14 & 0.77 & 0.01 & -0.13 \\
\hline Belgium & 2.36 & 4.24 & 1.01 & -0.48 \\
\hline Denmark & 4.59 & 4.37 & 1.71 & 0.16 \\
\hline \multicolumn{5}{|c|}{ Intermediate Currencies } \\
\hline France & 6.53 & 5.02 & 2.31 & 0.01 \\
\hline Ireland & 12.90 & 3.02 & 3.49 & 1.96 \\
\hline \multicolumn{5}{|l|}{ Soft Currencies } \\
\hline United Kingdom & 12.90 & 0.89 & 6.68 & 2.57 \\
\hline Italy & 17.28 & 5.26 & 4.08 & 6.21 \\
\hline Spain & 12.35 & 6.54 & 3.51 & 5.16 \\
\hline Greece & 13.24 & 13.02 & 18.75 & 10.23 \\
\hline Portugal & 20.83 & 14.16 & 10.64 & 2.88 \\
\hline \multicolumn{5}{|l|}{ Non-EU Members } \\
\hline Austria & 0.12 & -0.71 & -0.12 & 0.19 \\
\hline Norway & 4.92 & 1.08 & 6.61 & 2.29 \\
\hline Finland & 8.83 & -0.32 & 3.06 & 6.83 \\
\hline Sweden & 8.41 & 3.83 & 5.35 & 6.18 \\
\hline AVERAGE & 9.03 & 4.37 & 4.79 & 3.15 \\
\hline
\end{tabular}

B. Coefficients of variation of nominal exchange rates against the DM

$1973-78$

1979-83

1984-89

1990-94

\begin{tabular}{|c|c|c|c|c|}
\hline \multicolumn{5}{|l|}{ Hard Currencies } \\
\hline Netherlands & 2.15 & 1.18 & 0.31 & 0.43 \\
\hline Belgium & 2.80 & 9.84 & 1.55 & 1.17 \\
\hline Denmark & 7.20 & 7.99 & 2.85 & 1.57 \\
\hline \multicolumn{5}{|c|}{ Intermediate Currencies } \\
\hline France & 11.00 & 10.74 & 4.59 & 1.00 \\
\hline Ireland & 20.47 & 6.75 & 7.02 & 4.83 \\
\hline \multicolumn{5}{|l|}{ Soft Currencies } \\
\hline U.K. & 20.47 & 7.43 & 10.91 & 8.11 \\
\hline Italy & 24.02 & 10.64 & 6.63 & 12.56 \\
\hline Spain & 23.14 & 16.31 & 7.38 & 11.65 \\
\hline Greece & 18.43 & 18.98 & 26.54 & 14.66 \\
\hline Portugal & 35.65 & 21.75 & 17.57 & 7.31 \\
\hline \multicolumn{5}{|c|}{ Non-EU Members } \\
\hline Austria & 1.63 & 1.48 & 0.23 & 0.23 \\
\hline Norway & 8.28 & 4.89 & 11.40 & 5.00 \\
\hline Finland & 14.24 & 5.63 & 6.06 & 16.08 \\
\hline Sweden & 12.54 & 12.20 & 8.23 & 13.00 \\
\hline AVERAGE & 14.43 & 9.70 & 7.95 & 6.97 \\
\hline
\end{tabular}


to give up its exchange-rate autonomy. ${ }^{9}$ This is the case where exchange-rate policy would otherwise be superfluous, either because it would be ineffective or because it could better be carried out by a bloc of national monetary authorities rather than alone. High levels of factor mobility among countries make individual national currency policies ineffective, while production structures that imply correlated exogenous shocks make such policies unnecessary. The more mobile factors are across countries and the more similar their susceptibility to external shocks, the more desirable is a monetary union.

Scholars quickly concluded that this was unlikely to explain very much of European currency policy. There was too little labor mobility among European countries, and too little correlation among exogenous shocks, to justify the level of interest in currency unification. Europe was not an OCA, and even the "hard core" of the EMS may not have been one at the time it was established. ${ }^{10}$ Of course, on both dimensions there is variation among EU member states, so that some might be more appropriate members of a currency union than others. OCA criteria may have had differential effects on different countries that are worth considering. To assess the degree to which OCA criteria affected currency policy, I examine the impact of the similarity of each nation's industrial structure to that of Germany. (The appendix contains details on this and other measures used in this study.) This is the measure least likely to be endogenous to currency policy; such things as factor movements to and from Germany, another popular OCA proxy, are much more likely to be affected by real or anticipated currency policy than national industrial structure.

A second set of arguments, motivated in part by the generally recognized failure of the OCA approach to explain European monetary integration, focused on the possibility that European countries pegged to the DM to "import" German anti-inflationary credibility. ${ }^{11}$ Various arguments have been proposed as to why a currency peg might itself be more credible than simply committing to lower inflation. ${ }^{12}$ Along these lines,

9. Although the theory is about currency unions, it applies-perhaps less stringently-to fixed-rate systems. Canzoneri and Rogers 1990 discuss optimal-taxation (seignorage)-base d evaluations of currency union, but these seem unlikely to have been empirically particularly important.

10. Capital is more mobile than labor, but its relevance to adjustment is not so clear; capital controls were very common until the late 1980s. Two representative and influential studies are De Grauwe and Vanhaverbeke 1993 and Bayoumi and Eichengreen 1993. Frankel and Rose 1998 present the intriguing possibility that if "unsuitable " countries form a currency union they might evolve to be more suited over time, as their factor markets become more integrated and their production structures more similar.

11. See Giavazzi and Pagano 1989; and Weber 1991.

12. Most plausible are that the exchange rate is much more visible to market operators than is monetary policy and that deviating from a peg imposes more costs on policymakers because of its impact on both inflation and cross-border relative prices. Broz 2002 presents one version of the argument and some evidence about its applicability. However, the logic of the argument is not fully worked out-it is hard to see why a stated commitment to a currency target is more credible than a stated commitment to a domestic monetary target. Indeed, Fratianni and von Hagen 1991 argue against any substantial independent effect, but the evidence is hard to evaluate. 
it is commonly argued that European exchange-rate arrangements served as a nominal anchor for credibility-enhancing purposes. ${ }^{13}$

Certainly this could not explain German support for monetary integration, which is why some scholars focus on geopolitical rather than economic-policy grounds to explain German policy. ${ }^{14}$ It is also irrelevant to the important cases of Austria, Belgium/Luxembourg, Denmark, and the Netherlands, all of which were lowinflation countries that stood only to lose monetary credibility from linking their currencies to those of high-inflation countries. But there are undoubtedly European countries for which an attraction of the currency peg and single currency was the link to monetary-policy credibility.

There are no good proxies for government desire for anti-inflationary credibility. Just about anything that might increase the demand for credibility will also increase the difficulty of attaining it. For example, the rate of inflation presumably raises both the value of a credibility-enhancing peg and the cost of implementing one-so its impact is likely to be indeterminate. However, the literature suggests that governments with independent central banks have less need for the potential credibility enhancements of a fixed exchange rate. And others have argued that left-wing governments, with a generally inflation-acceptant reputation, are particularly likely to need the credibility a peg can provide. ${ }^{15}$ I thus assess the credibility argument, quite imperfectly, by seeing whether fixed rates are associated with the absence of central bank independence, or with leftist governments.

More recently, an alternative (or perhaps a supplement) to these monetary policy-based approaches has arisen, emphasizing the real effects of currency stability and currency union on cross-border trade and investment. Many scholars had been skeptical of such effects, as the prevailing wisdom held that deep forward and futures markets made currency volatility a trivial matter. But more recent research has found that reducing currency fluctuations, and especially sharing currencies, has a very substantial impact on cross-border trade. One controversial study found that currency unification tripled trade among union members. ${ }^{16}$ This has refocused attention on the ways in which currency policies can affect the environment for international trade and investment. By extension, it reinforces the plausibility of explanations of currency policy that focus on its impact on a country's trade and financial ties.

The argument made here builds on this third body of thought, emphasizing the real effects of currency policy and thus its impact on trade and investment. The effects of most importance to policy choice are of two sorts. First, just as currency

13. Milesi-Ferretti 1995, however, discusses how policymakers may have partisan electoral incentives not to tie their hands, inasmuch as precommitment strategies might reduce the electoral disadvantage s of potential opponents. If, for example, Left parties have a bad inflationary reputation, anything that reduces a government's ability to inflate reduces the electoral disadvantage of the Left.

14. Garrett 2001.

15. On central bank independence, Broz 2002 is a good example; on Left governments, see Simmons 1994.

16. Rose 2000. 
volatility increases the riskiness of cross-border transactions, exchange-rate stability reduces uncertainty about a price of great importance to those involved in crossborder economic activity. Second, currency movements affect the relative prices of home and foreign goods and services, and currency flexibility allows policymakers to vary the exchange rate, especially to devalue and make domestic products cheaper relative to foreign goods. ${ }^{17}$ Policymakers thus face a trade-off between exchangerate flexibility and exchange rate stability, and political economy factors-especially the relative importance of groups in society who stand to gain from one or the other side of the trade-off-have a powerful impact on their ultimate choice. ${ }^{18}$

The trade-off between exchange-rate stability and the freedom to vary the currency's value tends to pit two broad groups against one another, based on how highly they value the two conflicting goals. Both import-competing and exporting firms are helped by depreciation. For this reason, I expect opposition to fixing exchange rates to come especially from import-competing and exporting sectors. Conversely, the less threatening import- and export-market competition is to national producers, the less likely they are to oppose fixing the exchange rate.

On the other hand, exchange-rate volatility principally affects those with substantial cross-border contractual interests. Foreign investors, lenders, and borrowers dislike the unpredictability associated with substantial fluctuations in currency values, which are often not amenable to hedging at longer time horizons. In addition, volatility typically harms exporters of goods with limited pass-through, that is, goods whose prices to consumers do not fully reflect exchange-rate movements, usually due to substantial product differentiation. ${ }^{19}$ I expect those with cross-border economic interests to have been more oriented toward fixing the value of the national currency. ${ }^{20}$

17. Although governments cannot affect the real (inflation-adjusted) exchange rate at will, available evidence is strong that policy can have a powerful impact over the medium run, usually estimated as four to seven years. For surveys, see Frankel and Rose 1995; and Rogoff 1996.

18. The argument here is closely related to that made in Frieden and Stein 2001 and tested in the Latin American context in Frieden, Ghezzi, and Stein 2001. It is consistent with the long-term neutrality of money and the efficiency of forward markets: short- and medium-term factors are politically relevant, and forward markets are limited in their ability to protect economic agents far into the future.

19. Pass-through refers to the extent to which movements in exchange rates are reflected in product prices. Some goods, especially highly standardized ones sold in highly competitive markets (for example, wheat, textiles), reflect exchange-rate changes immediately. Producers of other sorts of goods, especially more specialized and differentiated products in which quality, service, and customer loyalty-things related to market share-matter, are more reluctant to vary prices. This has been observed in such goods as transport equipment (think of the non-responsivenes s of the prices of Japanese cars in the United States to the dollar-yen exchange rate), commercial aircraft, and machine tools. Goldberg and Knetter 1997 is an excellent survey.

20. I recognize that there are somewhat heroic assumptions underlying these assertions and do not defend them here. Certainly currency volatility is less costly when it is mean-reverting, and forward contracts are valuable; uncertainty is simply a part of doing business, some firms make money on currency fluctuations, and limited pass-through cuts both ways (to mention a few of the most common objections). However, relatively simple models with some price stickiness can easily provide the results I assert. In any case, whether these effects are present, and are politically relevant, is an empirical question-one that I attempt to assess here. 
There is one category of firms that can be divided in confusing ways by this trade-off: manufactured exporters. In general, exporters favor maintaining the exchange rate as an active policy instrument. The exporters and import competers most sensitive to nominal exchange rate levels are those whose product prices are more or less fully passed through, typically standardized products such as commodities, clothing, footwear, and steel. But the impact of the level of the exchange rate is mitigated in the case of industries with little pass-through; an appreciation does not cause an analogous rise in the (foreign-currency) price of exports, nor does a depreciation significantly increase (domestic-currency) export prices. In these instances, the exchange risk is carried by the export-producer, so that currency volatility can be quite costly. A common example is that of automobiles, which are priced to local market conditions. If the yen appreciates against the DM, studies find, Japanese car exporters hold their German prices steady, out of fear that price increases would lose them market share. For this reason, exporters of specialized, product-differentiated manufactured goods-typically the most important European exporters-are less likely to want a weak exchange rate and more likely to value currency stability.

To summarize, I expect division between economic actors who support and oppose fixed rates for real rather than monetary reasons. Cross-border investors and financial actors, as well as export-competing producers of specialized manufactured goods, will be in favor of fixed rates. Producers of standardized import-competing and export goods-those in favor of maintaining the national ability to depreciate the currency-will be against fixed rates. This reflects the trade-off mentioned before, between stability and a predictable currency value, on the one hand, and the flexibility to alter currency values to facilitate competition with foreigners, on the other.

Of course, much nuance and complexity is still masked. There are firms for which the trade-off between reduced currency volatility and the loss of exchange rate autonomy is not clear, either because both are important or because neither is important. I also have (mostly for brevity's sake) ignored the interests of nontradable producers, such as public sector employees and small businesses, which typically favor maintaining monetary policy autonomy rather than sacrificing it to stabilize currency values that have little direct impact on them.

The principal argument of this study, then, is that exchange-rate policy has enough prominent real economic and distributional effects to matter politically. Specifically, principal supporters of fixing European exchange rates were firms and industries with major cross-border investments, markets, or other business interests; principal opponents were producers of standardized import-competing and export products. In national political debates, this sometimes took the form of allegations that monetary integration was a tool of big business, or that opposition to monetary integration came from more backward and uncompetitive sectors. I expect the support of the former for fixing exchange rates to be relatively constant, while the opposition of the latter should increase at times of a real appreciation and associated 
competitive difficulties for national producers. ${ }^{21}$ This distributional aspect of European currency politics has been absent in most analyses of European monetary integration, and contrasts with the general focus on the anti-inflationary effects of the thirty-year process of currency unification. ${ }^{22}$

My focus on special-interest considerations is not meant to deny the potential importance of other factors, but rather to redress an imbalance in the literature. While special interests are a natural starting point for most economic policy analyses, this has not been the case for exchange-rate policy. In fact, many analysts are skeptical of the view that there are constituencies for and against currency policy. Prominent macroeconomists believe that the distributional effects of currency regimes are unclear, small, or both, while many political scientists believe that substantial collective action problems preclude serious politicking over currency values. ${ }^{23}$ Both positions are open to challenge. Economically, almost every attempt to fix exchange rates involves substantial real appreciations, with equally substantial distributional implications. Even in the steady state, it is not obvious that volatility is distributionally neutral, both in general and with regard to exchange rates; at the very least, clear evidence for this hypothesis is still lacking. ${ }^{24}$ Politically, the extraordinary political prominence of exchange rates in history and today seems to call the assertion into question. From the 1860 s until the 1930 s, the gold standard was a major, and mass, political issue in most countries; since 1980, exchange rates have been domestic "high politics" in many developed and developing countries as well. $^{25}$

\section{The Principal Explanatory Variables}

Attempts to evaluate arguments based on the distributional effects of exchange-rate policies are hampered by the general unobservability of special-interest politics. In this article, I use two variables that can be interpreted as affecting policy by way of

21. Again, all this leaves out much detail. One of the more interesting features of the runup to EMU was that import competers in the likely core increasingly came to insist on including the peripheryespecially Italy and Spain-to eliminate the possibility of such "competitive depreciations" as those of 1992-4. Perhaps most striking in this regard is the position of import-competing French industries, which went from opponents of the EMS in the early 1980s to strong suppporters of a broad EMU by the mid 1990s. In the former period, EMS membership ruled out a French devaluation and led to a real appreciation; in the latter period, Italian and Spanish non-membershi p in EMU would have allowed them to depreciate against the franc, again causing a real appreciation of the French currency. The result was that potentially affected firms switched from opposition to French membership in the EMS to strong support for the inclusion of the entire EU in EMU.

22. For some exceptions, see the essays in Jones, Frieden, and Torres 1998; Pisani-Ferry, Hefeker, and Hallett 1997; and Hefeker 1997.

23. See Giovannini 1993 for an example of the former; and Gowa 1988 for a classic statement of the latter.

24. An interesting perspective on the potential costs - including distributional effects — of volatility is Inter-American Development Bank 1995. For arguments that currency volatility does matter, see Hefeker 1997; and Neumeyer 1998.

25. Frieden 1994 and 1997 b discuss the issue in a historical and contemporary perspective. 
their differentiated and distributionally relevant effects on particular groups. The first attempts to pick up the interests of manufacturers with significant intraEuropean export interests; the second tries to capture the interests of those facing significant import and export competition. Neither is unproblematic, but there are no readily available superior alternatives. The two variables are as follows.

1. Exports to the German currency bloc. As discussed above, I expect that producers of specialized manufactured products will seek to keep exchange rates stable. Of course, this is countered by concern for the level of the real exchange rate. Keeping this in mind, manufacturers where pricing to market is common tend to oppose currency volatility. This should be of special importance in European monetary politics to the extent that manufactured exports to Germany are significant. Here I use exports to the DM bloc, defined as Germany plus Benelux. The higher the share of manufactured exports to the DM zone as a share of gross domestic product (GDP), the more support I expect for stabilizing the currency with the DM. The use of the $\mathrm{DM}$ bloc as the relevant region is unimportant: overall manufactured exports to Germany alone, or to the broad EU, as a share of GDP are highly correlated with this, and their use yields nearly identical results. The variable name I use for this is MANUFACTURED EXPORTS TO DM ZONE AS PERCENTAGE OF GDP, and I expect the sign to be negative. (A negative sign implies that a higher value of the variable is associated with less devaluation and less volatility. The appendix describes all variables in detail.)

2. Import competition. On the other hand, some of the most significant pressures to depreciate (or not to join the snake or ERM) came from producers that stood to lose from their government's foregoing the ability to change the exchange rate to affect competitiveness. Although there is no ready way to measure concern about competitive pressures, one reasonable proxy is the rate of change in import and export competition. That is, where a country's producers are experiencing a surge in imports or a drop in exports, they are more likely to be interested in a depreciation and less supportive of fixing the exchange rate. This implies that a deterioration in the trade balance should increase support for depreciation and reduce support for a fixed rate. This is analogous to the common observation that increased import competition tends to increase protectionist pressures from affected industries. $^{26}$

In using this measure, I control for the state of the current account for important reasons. It would not be surprising if large current account defi-

26. It has analogous weaknesses. In fact, if producers can gain from a depreciation, or from trade protection, they should support these no matter how much import competition they face (even in the absence of import competition). Nonetheless, the virtually universal observation is that support for protection/depreciation is strongly affected by import competition. A variety of explanations for this have been proposed, but serious consideration of these is well beyond the scope of this article. 
cits were associated with depreciations, for they put direct currency-market pressure on the exchange rate. However, what I use here is the impact of changes in the trade balance controlling for the state of the current account. This measure can only plausibly be picking up particular sensitivity to trade relations, the state of imports and exports. This variable is not simply the economic impact of a trade deficit: a trade deficit that does not lead to a current account deficit does not put pressure on the currency in foreign exchange markets. It thus seems reasonable to regard it as an indicator of the position of national import-competers and export-competers. ${ }^{27}$ The greater the deterioration in the trade balance (again, controlling for the current account balance), the greater the pressures to depreciate. Here I use the change from the previous year in the trade balance as a share of GDP, so that a positive (negative) number is an improvement (deterioration). The variable name I use for this is CHANGE IN TRADE BALANCE AS PERCENT OF GDP, and I expect the sign to be negative.

The two proxies for private interests I use here are not as close as we might like to what we want to measure, the lobbying behavior of private interests. Nor do they cover all the private interests I argue should matter, especially those of cross-border investors. Better proxies, however, are difficult to identify, let alone obtain data on. The extent of intra-European trade is probably a reasonable approximation of the importance of stabilizing exchange rates for traders and export-oriented producers. But this ignores the interests of cross-border financial and investing interests-for the simple reason that data on them are essentially unavailable. One might imagine that foreign direct investment (FDI) among European countries would be easy to obtain. Unfortunately, this measure is only available for a few countries before the early 1980s, and even then with much error. When the statistical analysis is performed with FDI data, more than half of the observations have to be omitted, and the omitted countries are biased toward Southern Europe. It is thus not clear that these results (which are not reported here but which tend to be similar to those for manufactured exports) are valid. The FDI measures are in any case correlated (correlation coefficient of 0.54) with the manufactured export figures. It is, by the same token, extremely difficult to come up with reasonable proxies for privatesector concern about the ability to use the exchange rate to affect competitiveness. The strategy used here-to look at increased net imports as an indicator of how much competition producers face-has many flaws, but seems better than available alternatives. All in all, the two measures used are plausible, if imperfect, indicators

27. Of course, the trade balance also picks up exports, and this is also a measure of pressures from exporters for a "competitive depreciation." In a sense, the inclusion of overall levels of exports in the previous measure and consideration of changes in net imports in this measure provide a contrast between a structural or secular trend in manufacture exports, on the one hand, and year-to-year surges in net imports on the other. It seems legitimate to presume, at least as a first cut, that these are reasonable proxies for specialized exporting and import/export-competing interests, respectively. 
of important private sector interests in currency policy. In the absence of other suitable indicators, they constitute a reasonable first cut.

Alternative Explanatory Variables. As mentioned above, the principal alternative perspective emphasizes currency pegs as anti-inflationary commitment mechanisms; some attention is still paid to OCA theory. The variables I use to evaluate these arguments are as follows.

1. Credibility concerns. It is hard to imagine any clean measure of the demand for anti-inflationary credibility. Of course, high inflation implies a greater need for credibility, but it also implies a higher cost of achieving it. In addition, high inflation leads directly to currency depreciation when the authorities are not using the exchange rate as an anti-inflationary commitment device, which invalidates any simple expectation that high inflation should be generally associated with currency stability. Ideally, we would like a measure that reflects government need for, or use of, currency policy for credibility purposes; there is no simple way of assessing this. Here I use a series of measures all of which could plausibly be associated with government desires to enhance anti-inflationary credibility. None is a direct measure of the demand for credibility, but all are potentially related to it.

A. Central bank independence. Inasmuch as the independence of the central bank is associated with lower inflation, this should reduce the government's need for the anti-inflationary credibility that a currency peg is purported to provide, and thus reduce the likelihood of such a currency link. A more dependent central bank, on the other hand, should increase the demand for credibility and thus the likelihood of a currency peg. The measure used is the standard one created by a group of scholars in an influential study. ${ }^{28}$ Variable name (expected sign): CENTRAL BANK INDEPENDENCE $(+)$.

B. Partisan effects. To the extent that the Left is more inflation prone than the Right, we expect the Left to have a greater need for the sort of commitment technology that a currency link is expected to provide. So, the further Left a government, the more likely it is to choose the DM currency peg. The variable used here measures the partisan (Left-Right) nature of the cabinet in power; parties are coded on a widely accepted scale and weighted according to their importance in the cabinet. On this scale, lower numbers are more to the Left. (Alternate measures of the legislative center of gravity, or the government's ideology, which use similar scales, yield nearly identical results.) Variable name (expected sign): CABINET CENTER OF GRAVITY $(+)$. 
C. Government instability. It is a commonplace of macroeconomic political economy that less stable and/or more fragmented governments are particularly in need of monetary-policy credibility. So the more unstable and fragmented are governments, the more likely they should be to choose the DM link. I use two measures that are not closely related in institutional terms. The first is the share of all legislative seats held by the governing coalition, which indicates roughly the security of the government in office (a measure that uses share of all votes gives the same results). The bigger this seat share, the more stable the government, the less likely it is to need the currency as a commitment mechanism, and the less likely is a peg. The second measure is the number of parties in government, which gives a rough sense of the government's stability; more parties in government should increase the need for credibility and thus the propensity to link to the DM. ${ }^{29}$ Variable names (expected signs): PERCENTAGE OF SEATS HELD BY GOVERNMENT PARTIES, NUMBER OF GOVERNMENT PARTIES $(+,-)$.

None of these variables is, as noted, a direct measure of the demand for credibility. There is almost certainly no such direct measure, however, and all of the variables employed here have been used to evaluate credibility-based arguments in other studies. They are plausible proxies for a government's desire to use exchangerate policy for anti-inflationary credibility purposes.

2. Similarity of economic structure. In the OCA framework, the more similar national economies are, the less they need independent monetary policies. Here I use the correlation of a nation's industrial structure with that of Germany, which should indicate how different the exogenous shocks affecting the two countries are likely to be. Other related measures might be used. The correlation of a nation's trade structure with that of Germany has attractions (as it is more directly related to pressures on the exchange rate), but it risks endogeneity, as trade structure is much more likely to be affected by exchange-rate policy than overall industrial structure. In any case, the two measures are highly correlated and give nearly identical results. Other measures of OCA criteria tend to give rise to very similar categorizations of countries. ${ }^{30}$ In the case of the measure of industrial structure, the greater the correlation with Germany, the more likely the country is, by OCA criteria, to maintain a fixed exchange rate with the DM. Variable name (expected sign): industrial CORRELATION WITH Germany (-).

29. As any political scientist knows, this last measure has major problems. The number of parties in government is the direct result of the electoral system and will generally increase with proportionality or district magnitude. Inasmuch as we know that small open economies are generally much more likely to have the "purest" proportional representation schemes, this measure may well be closely related to openness. In fact, the correlation between the number of parties in government and manufacture dexports to the EU as a share of GDP is .18; the relationship is present but not particularly strong.

30. For example, Gros 1996. 
Control Variables. It is important to control for other factors that could be expected to affect exchange-rate movements. Macroeconomic conditions are foremost among these factors. I include these, and a couple of other common explanations of currency movements, as controls.

1. Macroeconomic conditions: Developments in national macroeconomic performance affect the propensity of a currency to depreciate. While the arguments for depreciation in each of these instances are problematic, generally speaking, particularly difficult years should be associated with a weaker currency.

A. Growth rates. Recessions may increase the propensity of monetary authorities to use depreciation to stimulate the economy. This depends on the trade-off between the income and substitution effects of a depreciation, but the consensus is that depreciations can be stimulative in the short run. Variable name (expected sign): LAGGED GROWTH RATE OF GDP (-) (that is, the stronger GDP growth, the less depreciation).

B. Unemployment. This can be expected to be significant for the same reason as the overall rate of economic growth. Variable name (expected sign): LAGGED UNEMPLOYMENT $(+)$.

C. The current account. The weaker a country's current account, the more downward pressure there will be on its currency and the likelier a depreciation. Note that this is the more or less purely economic effect mentioned above, for which I control to assess the independent impact of trends in imports and exports. Variable name (expected sign): LAGGED CURRENT ACCOUNT BALANCE AS PERCENTAGE OF GDP (-).

D. The terms of trade. The difference between movements in the country's terms of trade and those of Germany should affect the currency. The more the country's terms of trade deteriorate relative to Germany, the harder it should be to sustain a fixed exchange rate. A positive number here means that the terms of trade improved in the year relative to Germany's, while a negative number means they deteriorated. This implies that increases in the measure should make it easier to sustain the currency peg, and vice versa. Variable name (expected sign): DIFFERENCE IN terms of tRAde Relative to Germany $(-)$.

As can be seen from the variable names, all these are lagged one year except for the terms of trade figure. This is because policy can be expected to respond to such macroeconomic trends only with something of a delay, except for the terms of trade, which is a price-based measure and thus should have nearly immediate effect. In any case, using simultaneous (lagged, in the case of the terms of trade) data makes no difference to the results. The current account is expressed as a percentage of GDP, unemployment is a share of the labor force, GDP growth is a rate of (real) change, 
and the terms of trade are also a rate of change; all are expressed in percentage points.

2. Other controls: I include three other control variables, as they are commonly mentioned in the literature.

A. Membership in the snake or EMS. Of course, this is endogenous, but many believe that the snake and EMS, as international (regional) institutions, may have had a substantial independent impact on government behavior. This is a dummy variable that takes the value 1 if the country was a member of one of the two exchange rate mechanisms and zero otherwise. Variable name (expected sign): MEMBER OF SNAKE OR ERM $(-)$.

B. Election timing. In the spirit of the political business cycle, governments may be expected to manipulate the currency in the runup to an election. What in fact they do depends on the relative desirability of the stimulative effect of depreciation and the income effect of an appreciation. However, the traditional view of inflation and depreciation as similar in source and effect would lead us to expect elections to be associated with depreciations. The measure here is simply whether an election occurred in the year in question; the measure has its problems but is adequate for present purposes. Variable name (expected sign): ELECTION $(+)$.

C. Capital controls. Controls on capital movements should facilitate the maintenance of a fixed exchange rate. Of course, countries whose exchange rates face market skepticism for other reasons-such as macroeconomic fundamentals or political instability-are more likely to impose capital controls in the first place, so it may not be clear what to expect. However, in general it seems reasonable to expect countries with capital controls to be less likely to depreciate, all else being equal. The measure used is a composite created by Dennis Quinn and drawn from the International Monetary Fund's categorization of restrictions on capital movements. Variable name (expected sign): CAPITAL CONTROLS (-).

Table 2 presents simple descriptive statistics, showing the evolution of the means of all dependent and explanatory variables over the course of the period, divided into four subperiods (snake, early EMS, late EMS, and EMU). Table 3 presents a correlation matrix, which demonstrates several key points. First, the two dependent variables are very closely related $(0.82$ correlation). Second, several alternate measures of similar factors are closely related-for example, exports to the DM zone are highly correlated $(0.91)$ with exports to the EU more broadly. Third, where available, the correlation between FDI and exports among the same countries is relatively high ( 0.50 to 0.53 ). Fourth, there are very few correlations of note among explanatory variables - none above 0.5 - and most substantially below that. This is of particular importance because it would be reasonable to worry about the 
TABLE 2. Averages of all variables for all countries across periods

$1973-1978 \quad 1979-1983 \quad 1984-1989 \quad 1990-1994$

\begin{tabular}{|c|c|c|c|c|}
\hline Average DePreciation vs. DM & 9.034 & 4.963 & 4.227 & 3.147 \\
\hline COEFFICIENT OF VARIATION VS. DM & .033 & .027 & .019 & .019 \\
\hline INDUSTRIAL CORRELATION & .723 & .745 & .750 & .685 \\
\hline LAGGED GDP GROWTH & 3.671 & 2.240 & 2.731 & 1.651 \\
\hline LAGGED UNEMPLOYMENT (AS \% OF LABOR FORCE) & 3.969 & 6.681 & 9.170 & 8.810 \\
\hline LAGGED CURRENT ACCOUNT AS A \% OF GDP & -1.917 & -2.446 & -.762 & -.196 \\
\hline DiFFERENCE IN TERMS OF TRADE & .198 & 1.833 & -.820 & .078 \\
\hline MEMBERSHIP OF SNAKE OR ERM & .356 & .420 & .435 & .536 \\
\hline $\begin{array}{l}\text { CENTRAL BANK INDEPENDENCE } \\
(0-1,1 \text { MOST INDEPENDENT })\end{array}$ & .340 & .344 & .345 & .345 \\
\hline $\begin{array}{l}\text { CAPITAL CONTROLS } \\
\quad(0-15,15 \text { MOST CONTROLS })\end{array}$ & 6.030 & 5.150 & 4.244 & 2.207 \\
\hline $\begin{array}{l}\text { CABINET CENTER OF GRAVITY } \\
(1-5,5 \text { MOST RIGHT WING })\end{array}$ & 2.788 & 2.934 & 3.017 & 2.873 \\
\hline ELECTION & .286 & .357 & .298 & .271 \\
\hline NUMBER OF GOVERNMENT PARTIES & 2.035 & 1.832 & 2.100 & 2.255 \\
\hline Percent of Seats Held by Government Parties & 47.628 & 48.546 & 49.578 & 53.252 \\
\hline $\begin{array}{l}\text { MANUFACTURING EXPORTS TO DM ZONE AS A \% OF } \\
\text { GDP }\end{array}$ & 3.479 & 3.801 & 4.504 & 5.063 \\
\hline MANUFACTURING EXPORTS TO EC AS A \% OF GDP & 9.155 & 9.771 & 11.649 & 12.042 \\
\hline $\begin{array}{l}\text { Trade Balance Change as a Share of GDP } \\
\text { (LAGGED) }\end{array}$ & .039 & .153 & .142 & .548 \\
\hline
\end{tabular}

collinearity of many of the macroeconomic and monetary variables. It is reassuring to know that these problems are minimal.

\section{Analyzing European Monetary Politics: A Statistical Assessment}

The following statistical analysis uses the two measures in Table 1 as dependent variables. The annual depreciation rate is a better indicator of broad trends of currency policy; the volatility measure picks up both overall depreciations and intra-year currency fluctuations. Although the two are strongly correlated and yield similar results, where results differ is interesting in itself, as I discuss in the following section. I look at all current EU members except Germany, the anchor country, and Luxembourg, which shared a currency with Belgium. I also include Norway, as it often attempted to stabilize its currency against the DM, and there would have been little ex ante justification for excluding it at the outset of the sample. The period runs from the beginning of 1973 to the end of 1994, with annual observations. I stop the analysis in 1995 because at that point the EU was clearly in the runup to EMU, whose dynamic was quite different from that of the attempts to fix exchange rates that had come before. The explanatory variables are as described previously and in more detail in the appendix. The regressions 
using these panel data are all corrected for serial autocorrelation and heteroskedasticity, and panel-corrected standard errors are presented. ${ }^{31}$

Tables 4 and 5 present the results. The first column of each table presents the full model including all the variables. The second model reanalyzes the data, dropping the explanatory variables that do not come close to statistical significance. In the third model, variables from the second model that now fail to reach statistical significance are dropped.

The results are quite stable across specifications, as are the coefficients. Starting with Table 4, in which the left-hand-side variable is the annual depreciation rate, six explanatory variables are significant in all three models; only two other variables even come close to reaching significance in one or two specifications.

The three principal macroeconomic control variables are clearly important. The state of the current account, GDP growth, and the terms of trade (relative to Germany's) all have the expected signs and clearly had a powerful impact on exchange rates.

The proxies for the importance of real-rather than monetary-factors and of private interests are statistically significant and in the expected direction. First, the larger the country's manufactured exports to the DM zone as a share of GDP, the less likely it was to depreciate. Countries more commercially integrated with Germany were more likely to fix their currencies against that of Germany. This finding is consistent with the idea that export-oriented manufacturers, and multinational firms whose interests tend to track those of manufactured exporters, value currency stability. Second, deterioration in the trade balance (controlling for the current account balance), such as would be caused by an import surge, is strongly associated with depreciation. The more net import competition a country faced, the less likely the country was to fix its currency against the DM. This finding is consistent with the idea that the import- and export-competers faced with increased foreign competition pressed for a depreciation and, more generally, with the argument that currency policy was made with real considerations-its impact on trade and investment-strongly in mind.

The proxies used here to attempt to capture anti-inflationary credibility or OCA motivations for currency pegs were not significant in any specification. None of the measures associated with credibility concerns had any impact on the propensity to hold to a currency peg: neither the partisan composition of government, the two measures of general government strength or stability (the government's share of all seats and the number of parties in government), nor central bank independence had any impact. The correlation of national industrial structures with Germany's, the proxy for OCA status, is not significant.

The other factors considered yielded mixed results at best. Although there is some evidence that membership in the snake or ERM was associated with more stability

31. Data analysis was carried out on Stata 5.0 using the corrections for serial autocorrelation and panel heteroskedasticity (based on Beck and Katz) included in the Stata package. 
TABLE 3. Correlations among principal variables

\begin{tabular}{|c|c|c|c|c|c|c|c|c|c|}
\hline & DEPRECIATE & $\mathrm{COV}$ & GDPGROWTH & UNEMPLOY & CURRACCT & DIFFTOFT & INDUSTCORR & $\begin{array}{c}S N A K E / \\
E M S\end{array}$ & CABINETCG \\
\hline DEPRECIATE & 1.00 & & & & & & & & \\
\hline $\mathrm{COV}$ & 0.82 & 1.00 & & & & & & & \\
\hline GDPGROWTH & -0.19 & -0.15 & 1.00 & & & & & & \\
\hline UNEMPLOY & -0.08 & -0.15 & -0.02 & 1.00 & & & & & \\
\hline CURRACCT & -0.20 & -0.21 & 0.11 & -0.00 & 1.00 & & & & \\
\hline DIFFTOFT & -0.37 & -0.22 & 0.13 & -0.04 & -0.04 & 1.00 & & & \\
\hline INDUSTCORR & -0.20 & -0.30 & -0.00 & 0.43 & 0.16 & -0.08 & 1.00 & & \\
\hline SNAKE/EMS & -0.15 & -0.40 & -0.00 & 0.47 & 0.02 & -0.04 & 0.47 & 1.00 & \\
\hline CABINETCG & 0.07 & 0.06 & -0.07 & 0.38 & -0.11 & -0.08 & 0.14 & 0.21 & 1.00 \\
\hline ELECTION & 0.06 & 0.03 & -0.02 & 0.03 & -0.03 & 0.01 & 0.02 & 0.04 & 0.04 \\
\hline GOVSEATS & 0.03 & -0.04 & 0.10 & 0.07 & 0.04 & -0.06 & 0.02 & -0.01 & 0.05 \\
\hline GOVPARTIES & -0.09 & -0.08 & -0.01 & -0.04 & -0.04 & -0.01 & -0.01 & 0.16 & -0.04 \\
\hline CBI & 0.06 & -0.12 & -0.01 & -0.11 & -0.18 & -0.09 & -0.12 & -0.05 & 0.07 \\
\hline CAPCTRLS & 0.33 & 0.26 & 0.09 & -0.17 & -0.35 & 0.03 & -0.37 & -0.22 & -0.11 \\
\hline MFGEXP-DM & -0.21 & -0.39 & -0.04 & 0.09 & 0.21 & -0.10 & 0.48 & 0.38 & -0.03 \\
\hline MFGEXP-EC & -0.20 & -0.33 & -0.01 & 0.17 & 0.05 & -0.08 & 0.42 & 0.39 & -0.00 \\
\hline FDI-DM & -0.22 & -0.32 & 0.03 & 0.08 & 0.40 & -0.03 & 0.36 & 0.40 & -0.02 \\
\hline FDI-EC & -0.17 & -0.26 & 0.06 & 0.21 & 0.30 & -0.02 & 0.27 & 0.43 & 0.07 \\
\hline TRBALCHG & -0.18 & -0.22 & -0.38 & 0.09 & -0.41 & 0.17 & -0.01 & 0.15 & 0.08 \\
\hline INFLATION & 0.23 & 0.28 & -0.14 & 0.08 & -0.35 & 0.04 & 0.03 & -0.05 & 0.08 \\
\hline
\end{tabular}

against the DM, as expected, this variable does not reach statistical significance. ${ }^{32}$ There is little support for the notion that governments were more prone to depreciate in election years, as the results are not statistically significant. One variable is clearly significant but in the opposite direction to that usually expected. Capital controls, far from helping sustain the exchange rate against the DM, are associated with more depreciation. There is a clear problem of simultaneity here, though, as countries facing attacks on their currencies are more likely to impose capital controls.

32. However, the snake/ERM variable is mildly correlated (0.39) with manufactured exports so that there may be some collinearity problems. 


\begin{tabular}{|c|c|c|c|c|c|c|c|c|c|c|}
\hline-0.07 & 1.00 & & & & & & & & & \\
\hline 0.02 & 0.28 & 1.00 & & & & & & & & \\
\hline 0.04 & -0.02 & -0.11 & 1.00 & & & & & & & \\
\hline-0.02 & 0.06 & -0.16 & 0.04 & 1.00 & & & & & & \\
\hline 0.04 & 0.23 & 0.05 & 0.03 & -0.21 & 1.00 & & & & & \\
\hline 0.06 & 0.13 & 0.12 & -0.08 & -0.14 & 0.91 & 1.00 & & & & \\
\hline-0.03 & 0.24 & -0.13 & -0.11 & -0.46 & 0.53 & 0.37 & 1.00 & & & \\
\hline-0.00 & 0.28 & 0.02 & -0.11 & -0.45 & 0.56 & 0.50 & 0.83 & 1.00 & & \\
\hline 0.01 & -0.14 & 0.00 & -0.00 & 0.01 & 0.10 & 0.22 & -0.04 & 0.05 & 1.00 & \\
\hline-0.04 & -0.21 & -0.12 & -0.22 & 0.41 & -0.40 & -0.27 & -0.51 & -0.43 & 0.16 & 1.00 \\
\hline
\end{tabular}

Table 5 presents results of the same sort of regression analysis, using the coefficient of variation of the nominal exchange rate as the dependent variable. ${ }^{33}$ Results for the private-interest variables and macroeconomic controls are essentially as before: more manufactured exports to the DM zone, improvements in the trade balance, faster GDP growth, and a stronger current account are all associated with reduced volatility. Evolution in the terms of trade is significant in only one specification. Most other variables are as before: elections and government strength and stability are insignificant, and capital controls is significant in a direction opposite to that expected. So far the results are essentially the same as in the previous specification.

33. In the regression, unlike in Table 1, the relevant period is a year; this is the standard deviation of a currency's value (measured monthly) over its annual mean value. 
TABLE 4. Determinants of European depreciation rates.

Dependent variable $=$ depreciation rate

\begin{tabular}{|c|c|c|c|}
\hline & (1) & (2) & (3) \\
\hline Constant & $\begin{array}{c}3.660 \\
(3.703)\end{array}$ & $\begin{array}{c}3.305^{* *} \\
(1.409)\end{array}$ & $\begin{array}{c}3.633^{* *} \\
(1.372)\end{array}$ \\
\hline LAGGED GROWTH RATE OF GDP & $\begin{array}{l}-0.742^{* *} \\
(0.208)\end{array}$ & $\begin{array}{c}-0.647 * * \\
(0.203)\end{array}$ & $\begin{array}{c}-0.672 * * \\
(0.203)\end{array}$ \\
\hline LAGGED UNEMPLOYMENT & $\begin{array}{c}0.029 \\
(0.111)\end{array}$ & - & - \\
\hline $\begin{array}{l}\text { LAGGED CURRENT ACCOUNT BALANCE } \\
\text { AS PERCENTAGE OF GDP }\end{array}$ & $\begin{array}{l}-0.258 \\
(0.177)\end{array}$ & $\begin{array}{c}-0.393 * * \\
(0.180)\end{array}$ & $\begin{array}{c}-0.394 * * \\
(0.179)\end{array}$ \\
\hline $\begin{array}{l}\text { DIFFERENCE IN THE TERMS OF TRADE } \\
\text { RELATIVE TO GERMANY }\end{array}$ & $\begin{array}{l}-0.424 * * \\
(0.092)\end{array}$ & $\begin{array}{c}-0.391 * * \\
(0.093)\end{array}$ & $\begin{array}{c}-0.378 * * \\
(0.093)\end{array}$ \\
\hline $\begin{array}{l}\text { INDUSTRIAL CORRELATION WITH } \\
\text { GERMANY }\end{array}$ & $\begin{array}{l}-2.823 \\
(4.172)\end{array}$ & - & - \\
\hline MEMBER OF SNAKE OR ERM & $\begin{array}{l}-0.986 \\
(1.115)\end{array}$ & $\begin{array}{l}-1.549 \\
(0.957)\end{array}$ & $\begin{array}{l}-1.486 \\
(0.950)\end{array}$ \\
\hline CABINET CENTER OF GRAVITY & $\begin{array}{c}0.660 \\
(0.675)\end{array}$ & - & - \\
\hline ELECTION & $\begin{array}{l}1.258 \\
(0.897)\end{array}$ & $\begin{array}{c}1.233 \\
(0.911)\end{array}$ & - \\
\hline $\begin{array}{l}\text { PERCENT OF SEATS HELD BY } \\
\text { GOVERNMENT PARTIES }\end{array}$ & $\begin{array}{c}0.042 \\
(0.040)\end{array}$ & - & - \\
\hline NUMBER OF GOVERNMENT PARTIES & $\begin{array}{r}-0.379 \\
(0.374)\end{array}$ & - & - \\
\hline CENTRAL BANK INDEPENDENCE & $\begin{array}{r}-3.184 \\
(2.602)\end{array}$ & - & - \\
\hline CAPITAL CONTROLS & $\begin{array}{l}0.951^{* *} \\
(0.260)\end{array}$ & $\begin{array}{c}1.066^{* *} \\
(0.240)\end{array}$ & $\begin{array}{c}1.084^{* *} \\
(0.239)\end{array}$ \\
\hline $\begin{array}{l}\text { MANUFACTURED EXPORTS TO THE DM } \\
\text { ZONE AS A PERCENTAGE OF GDP }\end{array}$ & $\begin{array}{c}-0.289 * * \\
(0.147)\end{array}$ & $\begin{array}{c}-0.257^{* *} \\
(0.126)\end{array}$ & $\begin{array}{c}-0.255^{* *} \\
(0.125)\end{array}$ \\
\hline $\begin{array}{l}\text { CHANGE IN THE TRADE BALANCE AS A } \\
\text { PERCENTAGE OF GDP }\end{array}$ & $\begin{array}{l}-0.740 * * \\
(0.248)\end{array}$ & $\begin{array}{c}-0.541 * * \\
(0.247)\end{array}$ & $\begin{array}{c}-0.547 * * \\
(0.247)\end{array}$ \\
\hline $\mathrm{N}$ & 278 & 313 & 313 \\
\hline
\end{tabular}

Note: Standard errors appear in parentheses under the coefficients.

*Draws attention to coefficients significant at or above the $10 \%$ level.

**Draws attention to coefficients significant at or above the $5 \%$ level.

There are three differences between these results and those having to do with the depreciation rate; these differences have mixed implications for credibility-related perspectives. The partisan composition of government has an effect in the way generally anticipated by credibility-based arguments: the more left-wing the government, the less volatile the currency. But central bank independence does not: it is associated with less short-term volatility. In addition, snake/EMS membership is also associated with less volatility. The results imply therefore that these three factors are not strong enough to affect longer-term trends in currency values-the depreciation rate-but that they do reduce currency volatility. Left-wing govern- 
TABLE 5. Determinants of European currency variability. Dependent variable $=$ coefficient of variation

\begin{tabular}{|c|c|c|c|}
\hline & (1) & $(2)$ & (3) \\
\hline Constant & $\begin{array}{l}2.628 * * \\
(1.052)\end{array}$ & $\begin{array}{l}2.334 * * \\
(0.755)\end{array}$ & $\begin{array}{r}2.304 * * \\
(0.767)\end{array}$ \\
\hline LAGGED GROWTH RATE OF GDP & $\begin{array}{l}-0.121 * * \\
(0.055)\end{array}$ & $\begin{array}{l}-0.107 * * \\
(0.054)\end{array}$ & $\begin{array}{c}-0.112 * * \\
(0.052)\end{array}$ \\
\hline LAGGED UNEMPLOYMENT & $\begin{array}{l}-0.011 \\
(0.031)\end{array}$ & - & - \\
\hline $\begin{array}{l}\text { LAGGED CURRENT ACCOUNT AS A } \\
\text { PERCENTAGE OF GDP }\end{array}$ & $\begin{array}{l}-0.077 \\
(0.052)\end{array}$ & $\begin{array}{l}-0.110^{* *} \\
(0.051)\end{array}$ & $\begin{array}{c}-0.118 * * \\
(0.051)\end{array}$ \\
\hline $\begin{array}{l}\text { DIFFERENCE IN THE TERMS OF TRADE } \\
\text { RELATIVE TO GERMANY }\end{array}$ & $\begin{array}{l}-0.044 * \\
(0.025)\end{array}$ & $\begin{array}{l}-0.027 \\
(0.025)\end{array}$ & - \\
\hline INDUSTRIAL CORRELATION WITH GERMANY & $\begin{array}{l}0.278 \\
(1.189)\end{array}$ & - & - \\
\hline MEMBER OF SNAKE OR ERM & $\begin{array}{c}-1.060 * * \\
(0.306)\end{array}$ & $\begin{array}{l}-1.103 * * \\
(0.260)\end{array}$ & $\begin{array}{c}-1.077 * * \\
(0.266)\end{array}$ \\
\hline CABINET CENTER OF GRAVITY & $\begin{array}{l}0.473 * * \\
(0.186)\end{array}$ & $\begin{array}{l}0.498 * * \\
(0.182)\end{array}$ & $\begin{array}{r}0.516^{* *} \\
(0.183)\end{array}$ \\
\hline ELECTION & $\begin{array}{c}0.269 \\
(0.225)\end{array}$ & - & - \\
\hline $\begin{array}{l}\text { PERCENT OF SEATS HELD BY GOVERNMENT } \\
\text { PARTIES }\end{array}$ & $\begin{array}{c}0.002 \\
(0.012)\end{array}$ & - & - \\
\hline NUMBER OF GOVERNMENT PARTIES & $\begin{array}{l}-0.081 \\
(0.102)\end{array}$ & - & - \\
\hline CENTRAL BANK INDEPENDENCE & $\begin{array}{l}-2.730 * * \\
(0.765)\end{array}$ & $\begin{array}{l}-2.427 * * \\
(0.784)\end{array}$ & $\begin{array}{l}-2.567 * * \\
(0.777)\end{array}$ \\
\hline CAPITAL CONTROLS & $\begin{array}{c}0.100 \\
(0.073)\end{array}$ & $\begin{array}{l}0.144 * * \\
(0.068)\end{array}$ & $\begin{array}{r}0.139 * * \\
(0.069)\end{array}$ \\
\hline $\begin{array}{l}\text { MANUFACTURING EXPORTS TO THE DM ZONE } \\
\text { AS A PERCENTAGE OF GDP }\end{array}$ & $\begin{array}{c}-0.145^{* *} \\
(0.040)\end{array}$ & $\begin{array}{c}-0.136^{* *} \\
(0.032)\end{array}$ & $\begin{array}{c}-0.130 * * \\
(0.033)\end{array}$ \\
\hline $\begin{array}{l}\text { CHANGE IN THE TRADE BALANCE AS A } \\
\text { PERCENTAGE OF GDP }\end{array}$ & $\begin{array}{c}-0.188^{* *} \\
(0.067)\end{array}$ & $\begin{array}{c}-0.144^{* *} \\
(0.065)\end{array}$ & $\begin{array}{c}-0.149 * * \\
(0.064)\end{array}$ \\
\hline $\mathrm{N}$ & 278 & 305 & 312 \\
\hline
\end{tabular}

Note: Standard errors appear in parentheses under the coefficients.

*Draws attention to coefficients significant at or above the $10 \%$ level.

**Draws attention to coefficients significant at or above the $5 \%$ level.

ments do use a currency peg more than right-wing governments for short-term purposes; an independent central bank can stabilize the exchange rate in the short run more effectively than a dependent one, and membership in the snake/EMS increased national ability to stabilize currencies. Again, note that these variables reduce short-term volatility but not the propensity to depreciate itself; they also do not unambiguously support OCA or credibility-based arguments.

The substantive interpretation of most of the coefficients in the regressions is relatively straightforward. Those having to do with the average annual depreciation 
rate are easier to interpret than the coefficient of variation. Looking at Table 4, column 3, the variables expressed as percentage points (of GDP or as rates of change) are easily understood. One percentage point improvements in the GDP growth rate, current account as a share of GDP, and terms of trade relative to Germany are associated with $0.672,0.394$, and 0.378 percentage point reductions, respectively, in the currency's annual depreciation rate against the DM. Similarly, a one percentage point increase in manufactured exports to the DM zone as a share of GDP and a one percentage point improvement in the trade balance is associated with 0.255 and 0.547 percentage point reductions, respectively, in the rate of depreciation. These are all quite appreciable numbers.

Increasing capital controls by one point on the fifteen-point scale leads to an increase in the depreciation rate of 1.084 percent. This means little in and of itself; one way of seeing it is that a three-point difference, roughly equivalent to that between Norway and Greece, increases the depreciation rate by 3.252 percent a year.

The impact of explanatory variables on the coefficient of variation cannot be assessed so directly. A sense of their importance can be seen in the effect of a one standard deviation change in explanatory variables (holding all others at their means) on the volatility measure. By this measure, for example, a one standard deviation increase in the lagged GDP growth rate or the lagged current account is associated with a reduction in the coefficient of variation of 11.7 and 16.3 percent, respectively. An increase of one standard deviation in manufactured exports to the DM zone or the trade balance leads to 17.1 and 14.1 percent reductions in volatility, while such an increase in central bank independence is associated with a 15.1 percent decline in the coefficient of variation. On the other hand, one standard deviation's move to the right of the cabinet center of gravity, or increase in capital controls, is associated with 13.6 and 14.8 percent increases, respectively, in volatility.

These results are not generally supportive of credibility-oriented or OCA explanations of European currency policies. Only one significant result goes in the direction expected by an argument based on the credibility-enhancing effects of a fixed exchange rate: Left governments have less volatile exchange rates in the short run. But this applies only to month-to-month volatility, not to the overall longerterm stance of currency policy. It is extremely weak evidence, especially as the central bank independence variable is just as strongly significant, but in the opposite direction. To be sure, the difficulty of measuring the demand for anti-inflationary credibility implies that this evidence is not definitive. Nonetheless, while credibility motivations cannot be excluded, it is difficult to see any support for them in this analysis. Also, the data used here are not well suited to the assessment of the impact of elections on policy because each observation is a calendar year. Analyses of the data using a hazard model yield generally ambiguous results, although there is some mild evidence of an electoral exchange-rate cycle, in which politicians delay devaluations until after elections. This evidence is at best tentative, however. 
The principal results reported here are quite robust. Removing outliers-the Netherlands and Austria on one end, Greece and Portugal on the other-leaves the results essentially intact. This does reduce the significance of a few variables, which is not surprising, as it involves removing nearly one-third of all observations, but the major explanatory variables remain significant. When countries are omitted one by one, results are undisturbed. Adding year fixed effects only strengthens the results; adding country fixed effects has little impact, although (not surprisingly) it reduces the size of some coefficients.

Many versions of the empirical models were assessed, with no impact on the principal results, those pertaining to the proxies for real sectoral considerations. Manufactured exports to the EU as a whole (not just to the DM bloc) gives essentially identical results. Inclusion of the fiscal deficit (lagged or simultaneous) serves to make most other variables more significant and their coefficients larger. ${ }^{34}$ The fiscal deficit is itself significant and associated with more depreciation. Some scholars suggest a relationship between union density and better macroeconomic outcomes. ${ }^{35}$ Data on union membership as share of the labor force, however, are unavailable for Ireland, Spain, and Portugal, and unavailable elsewhere after 1989 or 1990. In any event, when these data are included (with almost half the observations lost) the variable is not significant and does not change the other variables in appreciable ways. Alternative proxies for credibility factors are hard to identify. When past inflation is included-in the form of a three-year moving average of the Consumer Price Index, lagged one year-it is associated with depreciation and volatility, running directly against the expected credibility argument, although this result is not statistically significant (and does not affect the impact of the principal explanatory variables). Such a finding is not particularly surprising, as discussed previously: currencies from countries with high inflation typically depreciate against other currencies. In other words, the direct impact of high inflation on the exchange rate dominates whatever effect it might have on the demand for credibility. In any case, the principal results support a high degree of confidence-especially concerning the two proxies for private-sector interests and the macroeconomic controls.

The results are summarized as follows:

1. Proxies for private-sector interests were significant and important. They were consistent with the argument that regionally oriented producers prefer a fixed currency, while import- and export-competers prefer flexibility. In other words, real factors were crucial. The more important manufactured exports to the DM zone (Germany and Benelux) were, the slower the depreciation rate and the less volatile the currency; an increase in net import

34. Not surprisingly, it does make the current account insignificant; it also makes central bank independence significant (but, again, not in the direction anticipated by credibility-based accounts).

35. Calmfors and Drifill 1988. 
competition, controlling for the current account, increased the depreciation rate and volatility significantly.

2. Macroeconomic control variables all had the expected effects. Such fundamentals as the current account balance, GDP growth, and the terms of trade relative to the anchor country all reduced the depreciation rate and currency volatility substantially.

3. Variables intended to capture inclinations to fix currencies to gain antiinflationary credibility were almost never significant. The only exception was that left-wing parties were more likely to hold the currency stable in the short run; there was no partisan difference in depreciation rates. A measure of suitability for membership in an OCA was never significant.

The results are in line with my expectations about the role of private interests. The level of commercial integration with Germany led to a more fixed exchange rate;increases in net import competition spurred depreciation. These two results provide a rough evaluation of the impact of private distributional interests-in the event of exporters of complex manufactures and of import-competers-on exchange-rate policy.

\section{Conclusions}

This study confirms the importance of real factors, and sectoral interests, in the development of European monetary integration. Higher levels of manufactured exports to Germany and Benelux and improvements in the trade balance are both associated with more fixed exchange rates against the DM. The empirical analysis also confirms the importance of macroeconomic conditions. I do not find appreciable support for arguments based on the alleged credibility-enhancing properties of currency pegs nor those based on OCA criteria.

The results show that distributionally motivated private interests, driven by the real effects of currency policy on trade and investment, are relevant to the making of exchange-rate policy. Specifically, exporters of sophisticated manufactures and cross-border investors seem to support stable exchange rates, while import- and export-competers favor depreciation. There is little or no evidence of the use of the exchange rate as a commitment mechanism for governments without anti-inflationary credibility or of the relevance of OCA considerations to exchange-rate policy choice. Those attempting to explain currency arrangements in Europe and elsewhere-most notably dollarization in Latin America and Euroization in Central and Eastern Europe-would be wise to consider the potential importance of such distributional consderations for the future of national exchange-rate policies. 


\section{Appendix}

\section{Definition and Sources of Explanatory Variables}

LAGGED GROWTH RATE OF GDP. Growth rate of GDP, lagged one year. Data for 1971-79 from United Nations 1985; for 1980-93 from OECD 1994.

LAGGED UNEMPLOYMENT. Percentage of the labor force unemployed, lagged one year. Data from OECD 1993, 1995, 1980; and United Nations 1985.

LAGGED CURRENT ACCOUNT AS PERCENTAGE OF GDP. Current account balance as a percentage of GDP, lagged one year. Data from OECD various years (a).

DIFFERENCE IN TERMS OF TRADE RELATIVE TO GERMANY. Percentage point change in the terms of trade over the previous year, relative to Germany's terms of trade. An increase in this figure signifies a deterioration in Germany's terms of trade relative to the country in question. Data from IMF 1996.

INDUSTRIAL CORRELATION WITH GERMANY. Correlation coefficient comparing the percent contribution to GDP of each ISIC one-digit category and two-digit categories for manufacturing (ISIC code 3). Because industrial structure changes slowly, the correlation coefficient is calculated for 1970, 1980, and 1990 only. Data from OECD various years (b). Where data were missing from the OECD statistics, data were taken from the United Nations various years (a).

MEMBER OF SNAKE OR ERM. Dichotomous variable $=1$ if country is a member of either snake or ERM, zero if not. Data obtained from BIS various years.

CABINET CENTER OF GRAVITY. Party composition of the cabinet, weighted by ideological scores using a scale constructed by Geoffrey Garrett. Data through 1991 provided by Geoffrey Garrett; updated using Müller 1994 and 1995; Sundberg 1993; and EJPR various years.

ELECTION. Number of elections per year (usually 1 or zero). Data obtained from Mackie and Rose 1991; Müller 1995 and 1994; Sundberg 1993; and EJPR various years.

PERCENTAGE OF SEATS HELD BY GOVERNMENT PARTIES. Percentage of legislative seats won by the government parties in the election at time $t$, where $t$ denotes the current observation. Constructed in Powell and Whitten 1993; updated using EJPR various years.

NUMBER OF GOVERNMENT PARTIES. Number of parties in government. Constructed in Powell and Whitten 1993; updated using EJPR various years.

CENTRAL BANK INDEPENDENCE. An index of central bank independence, running from zero (least independent) to 1 (most independent). Data from Cukierman, Webb, and Neyapti 1992. 
CAPITAL CONTROLS. A measure of capital controls constructed by Dennis Quinn, described in Quinn 1997. His 15 point-scale measures "openness;" it is inverted here so that a higher number means more capital controls. Data obtained from the author.

MANUFACTURED EXPORTS TO DM ZONE AS PERCENTAGE OF GDP. Value of manufactured (SITC codes 6-8) exports to Germany, Belgium, Luxembourg, and the Netherlands as a percentage of GDP. Data from United Nations various years (b).

CHANGE IN TRADE BALANCE AS PERCENTAGE OF GDP. Change in the trade balance from the previous year, in percentage terms. Constructed from data for trade balance and GDP and IMF various years.

\section{References}

Alesina, Alberto. 1989. Politics and Business Cycles in Industrial Democracies. Economic Policy 8:57-98.

Alesina, Alberto, and Lawrence H. Summers. 1993. Central Bank Independence and Macroeconomic Performance: Some Comparative Evidence. Journal of Money, Credit, and Banking 25 (2):151-62.

Alesina, Alberto, and Nouriel Roubini, with Gerald D. Cohen. 1997. Political Cycles and the Macroeconomy. Cambridge, Mass.: The MIT Press.

Bank for International Settlements (BIS). Various years. Annual Reports. Basel: BIS.

Bayoumi, Tamim, and Barry Eichengreen. 1993. Shocking Aspects of European Monetary Unification. In Adjustment and Growth in the European Monetary Union, edited by Francisco Torres and Francesco Giavazzi. Cambridge: Cambridge University Press.

Bernhard, William, Lawrence Broz, and William Clark. 2002. The Political Economy of Monetary Institutions: An Introduction. International Organization 56 (4):693-723.

Bernhard, William, and David Leblang. 1999. Democratic Institutions and Exchange Rate Commitments. International Organization 53 (1):71-97.

Blackburn, Keith, and Michael Christensen. 1989. Macroeconomic Policy and Policy Credibility: Theories and Evidence. Journal of Economic Literature 27 (1):1-45.

Broz, J. Lawrence. 2002. Political system transparency and monetary commitment regimes. International Organization 56 (4):863-89.

Canzoneri, Matthew, and Carol Ann Rogers. 1990. Is the European Community an Optimal Currency Area? Optimal Taxation Versus the Cost of Multiple Currencies. American Economic Review 80 (3):419-33.

Cukierman, Alex, Steven Webb, and Bilin Neyapti. 1992. Measuring the Independenc e of Central Banks and its Effect on Policy Outcomes. World Bank Economic Review 6 (1):353-98.

De Grauwe, Paul, and Wim Vanhaverbeke. 1993. Is Europe an Optimum Currency Area? Evidence from Regional Data. In Policy Issues in the Operation of Currency Areas, edited by Paul Masson and Mark Taylor. Cambridge: Cambridge University Press.

European Journal of Political Research (EJPR). Various years. European Journal of Political Research. Dordrecht, Netherlands: Kluwer Academic Publishers.

Frankel, Jeffrey A., and Andrew Rose. 1995. Empirical research on nominal exchange rates. In Handbook of International Economics volume 3, edited by Gene Grossman and Kenneth Rogoff. Amsterdam: North-Holland.

- 1998. The Endogeneity of the Optimum Currency Area Criteria. Economic Journal. 108 (449): $1009-25$.

Frankel, Jeffrey A., and Shang-Jin Wei. 1995. European Integration and the Regionalization of World Trade and Currencies: The Economics and the Politics. In Monetary and Fiscal Policy in an Integrated Europe, edited by Barry Eichengreen, Jeffry Frieden, and Jürgen von Hagen. New York: Springer. 
Fratianni, Michele, and Jürgen von Hagen. 1991. The European Monetary System and European Monetary Union. Boulder, Colo.: Westview Press.

Frieden, Jeffry. 1994. Exchange Rate Politics: Contemporary Lessons from American History. Review of International Political Economy 1 (1):81-103.

- 1997a. Economic liberalization and the politics of European monetary integration. In Liberalization and Foreign Policy, edited by Miles Kahler. New York: Columbia University Press.

— 1997b. Monetary Populism in Nineteenth-Century America: An Open Economy Interpretation. Journal of Economic History 57(2):367-95.

2001. Making Commitments: France and Italy in the European Monetary System, 1979-1985 . In The Political Economy of European Monetary Unification Second edition, edited by Barry Eichengreen and Jeffry Frieden, 23-47. Boulder, Colo.: Westview Press.

Frieden, Jeffry, Piero Ghezzi, and Ernesto Stein. 2001. Politics and Exchange Rates: A Cross-Country Approach to Latin America. In The Currency Game: Exchange Rate Politics in Latin America, edited by Jeffry Frieden and Ernesto Stein. Baltimore, Md.: Johns Hopkins University Press.

Frieden, Jeffry, and Ernesto Stein. 2001. The Political Economy of Exchange Rate Policy in Latin America: An Analytical Overview. In The Currency Game: Exchange Rate Politics in Latin America, edited by Jeffry Frieden and Ernesto Stein. Baltimore, Md.: Johns Hopkins University Press.

Garrett, Geoffrey. 2001. The Politics of Maastricht. In The Political Economy of European Monetary Unification Second edition, edited by Barry Eichengreen and Jeffry Frieden, 111-30. Boulder, Colo.: Westview Press.

Giavazzi, Francesco and Marco Pagano. 1989. The Advantage of Tying One's Hands: EMS Discipline and Central Bank Credibility. European Economic Review 32 (5):1055-75.

Goldberg, Penelopi Koujianou, and Michael M. Knetter. 1997. Goods Prices and Exchange Rates: What Have We Learned? Journal of Economic Literature 35 (3):1243-72.

Gowa, Joanne. 1988. Public Goods and Political Institutions: Trade and Monetary Policy Processes in the United States. International Organization 42 (1):15-32.

Grilli, Vittorio, Donato Masciandaro, and Guido Tabellini. 1991. Political and Monetary Institutions and Public Policies in the Industrial Countries. Economic Policy 13 (October):341-92.

Gros, Daniel. 1996. Towards Economic and Monetary Union: Problems and Prospects. Brussels: Centre for European Policy Studies.

Gros, Daniel, and Niels Thygesen. 1992. European Monetary Integration. London: Longman.

Hefeker, Carsten. 1997. Interest Groups and Monetary Integration: The Political Economy of Exchange Regime Choice. Boulder, Colo.: Westview Press.

Inter-American Development Bank. 1995. Overcoming Volatility. Washington, D.C.: Inter-American Development Bank.

International Monetary Fund (IMF). 1996. International Financial Statistics Yearbook. Washington, D.C.: IMF.

International Monetary Fund (IMF). Various years. International Financial Statistics Yearbook. Washington, D.C.: IMF.

Jones, Erik, Jeffry Frieden, and Francisco Torres. 1998. EMU and the Smaller Countries: Joining Europe's Monetary Club. New York: St. Martin's Press.

Mackie, Thomas T., and Richard Rose. 1991. International Almanac of Electoral History. Washington, D.C.: Congressional Quarterly.

Masson, Paul, and Mark Taylor. 1993. Currency Unions: A Survey of the Issues. In Policy Issues in the Operation of Currency Areas, edited by Paul Masson and Mark Taylor. Cambridge: Cambridge University Press.

McKinnon, Ronald. 1963. Optimum Currency Areas. American Economic Review 53 (4):717-25.

Milesi-Ferretti, Gian Maria. 1995. The Disadvantage of Tying Their Hands: On the Political Economy of Policy Commitments. Economic Journal 105 (433):1381-402.

Moravcsik, Andrew. 1998. The Choice for Europe. Ithaca, N.Y.: Cornell University Press.

Müller, Wolfgang C. 1994. Austria. European Journal of Political Research 26 (3-4):241-46.

Müller, Wolfgang C. 1995. Austria. European Journal of Political Research 28 (3-4):277-89. 
Mundell, Robert. 1961. A Theory of Optimum Currency Areas. American Economic Review 51 (4):657-65.

Neumeyer, P. A. 1998. Currencies and the Allocation of Risk: The Welfare Effects of a Monetary Union. American Economic Review 88 (1):246-59.

Organization for Economic Cooperation and Development (OECD). 1980. Main Economic Indicators, Historical Studies, 1960-1979. Paris: OECD.

Organization for Economic Cooperation and Development (OECD). 1993. Main Economic Indicators, Historical Statistics, Prices, Labor and Wages, 1962-1991. Paris: OECD.

Organization for Economic Cooperation and Development (OECD). 1994. Historical Statistics: 19601993. Paris: OECD.

Organization for Economic Cooperation and Development (OECD). 1995. Economic Outlook 58 (December). Paris: OECD.

Organization for Economic Cooperation and Development (OECD). Various years (a). Economic Outlook. Paris: OECD.

Organization for Economic Cooperation and Development (OECD). Various years (b). Industrial Structure Statistics. Paris: OECD.

Pisani-Ferry, Jean, Carsten Hefeker, and Andrew Hughes Hallett. 1997. The Political Economy of EMU: France, Germany, and the UK. CEPS Paper Number 69. Brussels: Centre for European Policy Studies.

Powell, G. Bingham, Jr., and Guy D. Whitten. 1993. A Cross-National Analysis of Economic Voting. American Journal of Political Science 37 (2):391-414.

Price, Simon. 1997. Political Business Cycles and Macroeconomic Stability: A Survey. Public Choice 92 (3-4):407-427.

Quinn, Dennis. 1997. The Correlates of Change in International Financial Regulation. American Political Science Review 91 (3):531-52.

Rogoff, Kenneth. 1996. The Purchasing Power Parity Puzzle. Journal of Economic Literature 34 (2):647-88.

Rose, Andrew. 2000. One Money, One Market: Estimating the Effect of Common Currencies on Trade. Economic Policy 15 (30):7-46.

Simmons, Beth. 1994. Who Adjusts? Princeton: Princeton University Press.

Sundberg, Jan. 1993. Finland. European Journal of Political Research 24 (4):419-23.

Tavlas, George. 1994. The Theory of Monetary Integration. Open Economies Review 5 (2):211-30.

United Nations. 1985. Economic Survey of Europe in 1984-85. Geneva: United Nations Research and Planning Division.

United Nations. Various years (a). Industrial Statistics Yearbook. New York: United Nations Department of Economic and Social Affairs.

United Nations. Various years (b). Yearbook of International Trade Statistics. New York: United Nations Department of Economic and Social Affairs.

van der Ploeg, Frederick. 1989. The Political Economy of Overvaluation. Economic Journal 99 (397):850-55.

Weber, Axel. 1991. Reputation and Credibility in the European Monetary System. Economic Policy 12:57-102. 